\title{
Use of waste heat recovery from refrigeration system in a commercial facility - a case study
}

\author{
Agnieszka Zając $\mathrm{c}^{1, *}$ \\ ${ }^{1}$ Wroclaw University of Science and Technology, Faculty of Environmental Engineering, \\ Department of Air Conditioning, Heating, Gas Engineering and Air Protection, ul. Norwida 4/6, \\ 50-373 Wroclaw, Poland
}

\begin{abstract}
Still technological development is associated with huge energy consumption, and thus with the increasing use of constantly decreasing fossil fuel resources, the formation of greenhouse effect and an increase in atmospheric pollution with combustion products. In connection with the constant, increasing global energy consumption, including for refrigeration purposes, it is necessary to promote modern, cost-effective technologies that enable energy recovery in sanitary installations. This article discusses the problem of utilization of waste heat from the refrigeration process and presents the possibilities of acquiring this wasted heat and objectives of its use. The article was prepared on the basis of a technical and technological design of a real object in Wroclaw, which is a self-service grocery store.
\end{abstract}

\section{Introduction}

The principle of operation of each standard vapor-compression refrigeration device is based on the left-side thermodynamic cycle and consists that the heat taken from the evaporator $\left(\mathrm{Q}_{\mathrm{e}}\right.$ or $\mathrm{Q}_{\mathrm{L}}$ ) (coming from the cooled environment) and the energy supplied to the compressor drive $(\mathrm{W})$ are discharged outside the system in the condenser $\left(\mathrm{Q}_{\mathrm{c}}\right.$ or $\left.\mathrm{Q}_{\mathrm{H}}\right)$.

There are many handbooks, guides and books on refrigeration [1-6] but there is no information about waste heat recovery systems (WHRS). The articles often refer to prototype installations of waste heat recovery from a domestic refrigerator [7, 8].

Heat removed from this system, coming from both the process of desuperheating vapors, proper condensation and refrigerant subcooling, is most often wasted [9]. Today's technology makes it possible to recover the heat transported by the refrigerant and its rational use with relatively small investment outlays [10]. The implementation of heat recovery is possible by appropriate design or expansion of a traditional installation, which will recover wasted energy. As a result of such a procedure, the operating costs of the facility, associated with the preparation of hot domestic water and heating, can be significantly reduced $[11,12]$. In order to prevent the condensation from being disturbed by the heat recovery process, e.g. due to its periodicity, separate heat exchangers for its recovery are used, located in series or in parallel to the condenser [13, 14].

\footnotetext{
* Corresponding author: agnieszka.zajac@pwr.edu.pl
} 
Fig. 1 shows the operation diagram of a typical chiller and a device with the possibility of recovering the heat of condensation and the compressed vapor superheat.

a)

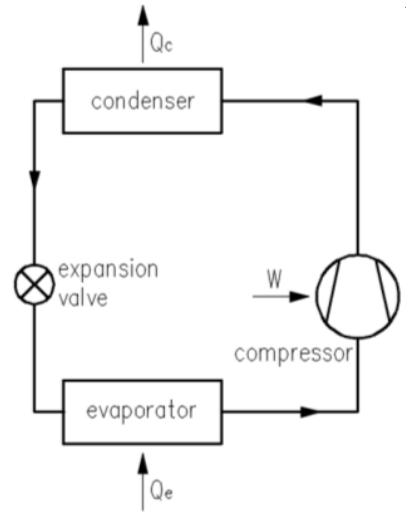

b)

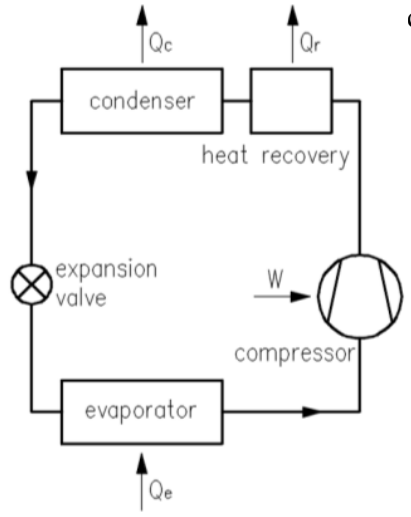

c)

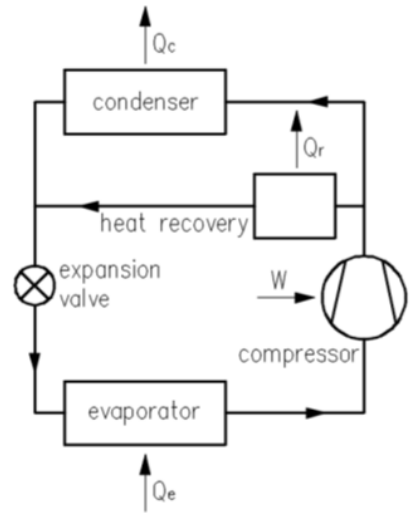

Fig. 1. The operation diagram of : a) typical chiller, b) device with heat recovery superheated vapor and the heat of condensation in a series connection, c) in a parallel connection.

In terms of energy, heat recovery from a refrigeration installation is always beneficial, while the economic effect depends on many factors.

This is influenced by:

- type of refrigeration installation (indirect, direct),

- the use of heat (domestic hot water, central heating, air heaters),

- operating time of the installation (number of hours, whether the work is continuous or periodic or the installation works all year round or is seasonal - summer, winter), - required parameters (flow temperature of the recovered heat source, condensing temperature and pressure, discharge temperature of the refrigerant vapor), - ease of use, maintenance-free automation system controlling the work of subassemblies and combining the recovery system with a backup heating system.

When designing a refrigeration installation, it should be remembered that the heat recovery system must not have a negative impact on the energy efficiency of the refrigeration unit, and the main function of the modernized device still has to be to provide a cooling effect with unchanged parameters. In addition, it is necessary to realize that most of the waste heat can be obtained when the refrigeration units operate at the highest efficiency, i.e. in the summer, while the greatest demand for this heat occurs in the winter [15]. An exception may be the year-round need to prepare domestic hot water for sanitary and industrial purposes. Therefore, the decision on the application of waste heat recovery should be taken after a thorough analysis of the functioning of the building, the cooling installation used in it and the purpose of using this energy.

\section{Characteristics of commercial facilities}

Currently, there is a huge demand and interest in the development of commercial infrastructure, and thus the construction of large self-service grocery stores (supermarkets). During the design process, it is necessary to perform detailed heat balances to determine the size of the refrigeration installation and to estimate the heat recovery capacity. 
Modern supermarkets and hypermarkets are characterized by large retail areas, adapted to serve a huge number of customers. The number of people in the supermarket is relatively difficult to estimate. In addition to employees whose number is known, there are customers whose number varies throughout the day and hours of use. The number of visitors depends on the size and location of the object. On a weekday the greatest density of people can be expected in the afternoon. On the other hand, people do their shopping more often in the mornings or during the noon hours on non-working days. Completely different laws are governed by so-called promotions and sales, where the number of people is almost impossible to predict.

Characteristic for thermal loads of commercial facilities are significant profits from electric lighting. The higher the store's standard, the better the lighting of the goods sold. Profits from lighting are permanent profits, independent of the time of day or season. The same is true for profits from technological devices. In grocery stores, we can meet cash registers, product weights, barbecues in the catering department and refrigerators for cold drinks. In addition, there are many open refrigerated counters, cooling merchandisers and freezing displays (gondolas) in supermarkets, which, in addition to cooling the food inside them, also cool the air in their area, which should be taken into account when balancing heat in the sales hall. When the condensers of the above-mentioned devices are located in the sales hall then there is a heat gain from the technology, whereas when these condensers are placed outside the balance limit, heat losses from the technology should be taken into account. It is the condensers of refrigeration units located outside the sales hall that are the main source of energy for heat recovery.

In addition to the internal heat gains described above, these stores also have external thermal loads (related to the mass of the building, glazing, sun exposure, use or absence of sunshades, the season), but in the total heat balance of typical self-service stores they do not matter.

Particular attention is paid not only to the surroundings and interior design, but also to the air quality in which both sellers and buyers stay, on that type of stores. It should be remembered that providing a suitable microclimate for visitors is particularly important, because customers who feel thermal comfort may stay in such a store for longer, and thus allow themselves to buy more. An important problem is choosing the right air temperature in the supermarket. Too high temperature will lead to spoilage of stored food. Too low temperature will cause discomfort to the occupants. It is in winter that it is particularly difficult to determine the correct internal temperature, because customers are dressed in winter outerwear, and the staff are dressed in company uniforms, just like in the summer. One of the solutions is to keep the temperature lower in whole hall and use local heaters in places of permanent staff staying. It is also worth remembering to use air curtains near the store entrance, which will prevent cold outside air from entering the interior during the winter (unpleasant feeling of drafts) and warm in summer time. Too much savings on air quality and air parameters in commercial facilities instead of the planned profits can bring losses, by reducing sales.

Heating and ventilation (air conditioning) in commercial buildings fulfill a very important role, and a properly designed system should ensure thermal comfort conditions in a cheap and energy-saving way, so that the customer, the owner and the seller are fully satisfied. 


\section{The solution used in the designed store}

An example of an object in which waste heat recovery system (WHRS) were designed and installed is located in Wroclaw (in Fig. 2 there is a throw of the building). The store's sales area is $700 \mathrm{~m}^{2}$. Next to the store there are two backrooms, which include managerial, social, warehouse, cleaning rooms, employee locker rooms, cold stores and freezer room with a total area of $380 \mathrm{~m}^{2}$.

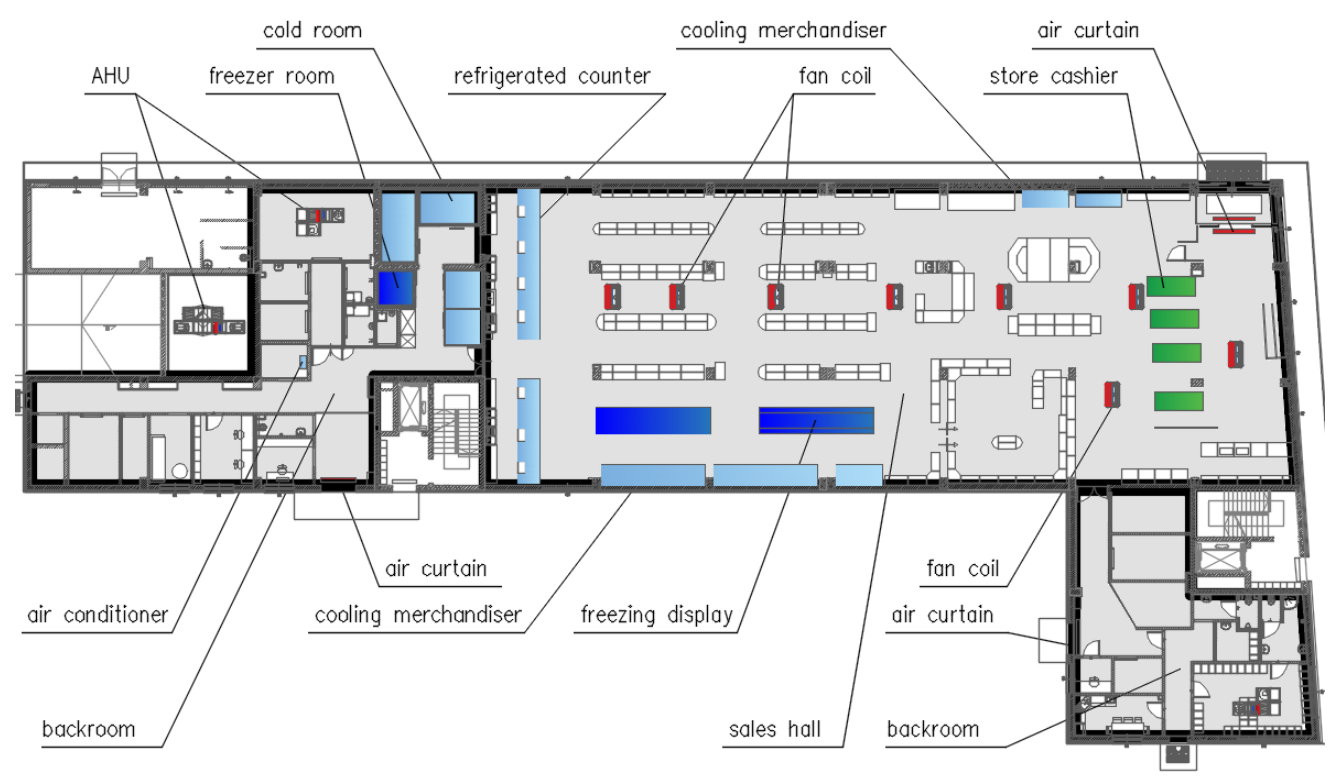

Fig. 2. The projection of a commercial building with a marked sales hall, backrooms and equipment.

The main objective of the project was the installation of refrigeration for reducing and maintaining low temperature in refrigerators and freezers in the store and in rooms for food storage in the back. The designers' tasks also included the design of ventilation systems with year-round temperature normalization and heating systems in both sales room and two backrooms. Thanks to the enlargement of the installation with appropriate exchangers for heat recovery and a tank for heated water and incurring one-off investment costs, free hot water and energy for heating the building were obtained. Such rebuild of the installation, with an additional heat recovery system, allowed to significantly reduce operating costs of the entire facility.

The following accompanying installations were made in the building:

- installation of waste heat recovery superheating compressed refrigerant vapor for the production of hot domestic water for sanitary or communal-household purposes,

- installation of waste heat recovery condensing heating working for the needs of air curtains, heaters in air handling units (AHU) and fan coils, as well as zoned underfloor heating, where cash boxes are located,

- installation of cooling system made in an indirect system for the needs of coolers in air handling units and fan coils. 
The effect of refrigeration in the analyzed object, due to the technology of the commercial facilities, is carried out by three separate refrigeration systems. Table 1 presents the division into groups depending on the operating temperatures of the refrigeration system.

The freezer room has an independent refrigeration system to provide a reserve in the event of failure of the freezer displays. The goods (frozen food, ice cream) from the freezer displays can then be stored in the freezer room.

Table 1. Type of refrigeration installation depending on the operating temperature.

\begin{tabular}{|c|c|c|c|}
\hline $\begin{array}{c}\text { Type of } \\
\text { refrigeration } \\
\text { installation }\end{array}$ & $\begin{array}{c}\text { Where the refrigerant } \\
\text { goes }\end{array}$ & $\begin{array}{l}\text { Evaporation } \\
\text { temperature }\end{array}$ & Thermal power \\
\hline $\begin{array}{l}\text { installation working } \\
\text { on the needs of } \\
\text { devices with } \\
\text { plus operating } \\
\text { temperature } \\
\left(+2{ }^{\circ} \mathrm{C} \div+4{ }^{\circ} \mathrm{C}\right)\end{array}$ & $\begin{array}{l}\text { - } 4 \text { cold rooms (refrigeration } \\
\text { chambers) in the back of } \\
\text { the store (dairy products, } \\
\text { meats, red meat, poultry), } \\
\text { - } 7 \text { exposition refrigerated } \\
\text { counters, } \\
\text { - } 7 \text { cooling merchandisers } \\
\text { in the sales hall, } \\
\text { - air conditioner operates } \\
\text { server room, } \\
\text { - indirect heat exchanger } \\
\text { for ventilation (heat-transfer } \\
\text { fluid supplies coolers } \\
\text { in } 3 \text { air handling units } \\
\text { and } 8 \text { coolers in fan coils } \\
\text { placed in the sales hall), }\end{array}$ & $-8^{\circ} \mathrm{C}--10^{\circ} \mathrm{C}$ & $\begin{array}{l}\text { the total thermal power } \\
\text { of the compressor unit } \\
\mathrm{Q}_{\mathrm{e}}=120 \mathrm{~kW} \text {, } \\
\text { the heat of superheated } \\
\text { vapor and the heat } \\
\text { of condensation } \\
\text { to be recovered is } \\
\mathrm{Q}_{\mathrm{sh}}+\mathrm{Q}_{\mathrm{c}}=170 \mathrm{~kW}\end{array}$ \\
\hline $\begin{array}{l}\text { installation working } \\
\text { on the needs of } \\
\text { devices with } \\
\text { minus operating } \\
\text { temperature } \\
\left(-18^{\circ} \mathrm{C}--22^{\circ} \mathrm{C}\right)\end{array}$ & $\begin{array}{l}\text { - } 4 \text { freezing displays } \\
\text { on the sales hall }\end{array}$ & $-38^{\circ} \mathrm{C}--40^{\circ} \mathrm{C}$ & $\begin{array}{l}\text { thermal power } \\
\text { of the compressor unit } \\
\mathrm{Q}_{\mathrm{e}}=10 \mathrm{~kW}, \\
\text { heat of superheated } \\
\text { vapor and heat } \\
\text { of condensation } \\
\text { to be recovered is } \\
\mathrm{Q}_{\mathrm{sh}}+\mathrm{Q}_{\mathrm{c}}=20 \mathrm{~kW}\end{array}$ \\
\hline $\begin{array}{l}\text { installation working } \\
\text { for the needs of } \\
\text { the chamber } \\
\text { (at a working } \\
\text { temperature of } \\
-18^{\circ} \mathrm{C}--22^{\circ} \mathrm{C} \text { ) }\end{array}$ & $\begin{array}{l}\text { - freezer room (frozen food } \\
\text { and ice cream) located } \\
\text { in the back of the store }\end{array}$ & $-28^{\circ} \mathrm{C}--30^{\circ} \mathrm{C}$ & $\begin{array}{l}\text { thermal power } \\
\text { of the compressor unit } \\
\mathrm{Q}_{\mathrm{e}}=2.5 \mathrm{~kW} \text {, } \\
\text { the total heat } \\
\text { of condensation } \\
\text { to be recovered is } \\
\mathrm{Q}_{\mathrm{c}}=5 \mathrm{~kW}\end{array}$ \\
\hline
\end{tabular}

The designers founded temperature of condensation in all condensers at $+50{ }^{\circ} \mathrm{C}$. This temperature results from the intake of extremely unfavorable outdoor conditions (outside temperature $35^{\circ} \mathrm{C}$ ) that may occur during the summer. This determines the temperature of the heat-transfer fluid in the range of $38-45^{\circ} \mathrm{C}$. In this temperature range, works also a dry-cooler, whose power has been set at $195 \mathrm{~kW}$. 
In summer conditions, both air curtains and other heat receivers (heaters in air handling units and fan coils, underfloor heating) do not need heat, so the heat of condensation is removed by dry-cooler outside. The heat recovered from the refrigeration installation is designed exclusively for heating domestic hot water in summer.

The whole system works on the R507 refrigerant. This refrigerant has a zero ozone depletion potential (ODP $=0$ ). In contrast to refrigerants such as R407C or R404a, $\mathrm{R} 507$ is an azeotropic mixture - it does not have non-isothermal evaporation and condensation processes, which is a great advantage during the operation of equipment and any repair service. The heat-transfer fluid (secondary coolant) used is a $30 \%$ solution of water and ethylene glycol by volume. An identical heat-transfer fluid was used for the indirect heat exchanger to ventilation purposes.

Fig. 3 presents a schematic diagram of technical and technological installations used in a self-service supermarket.

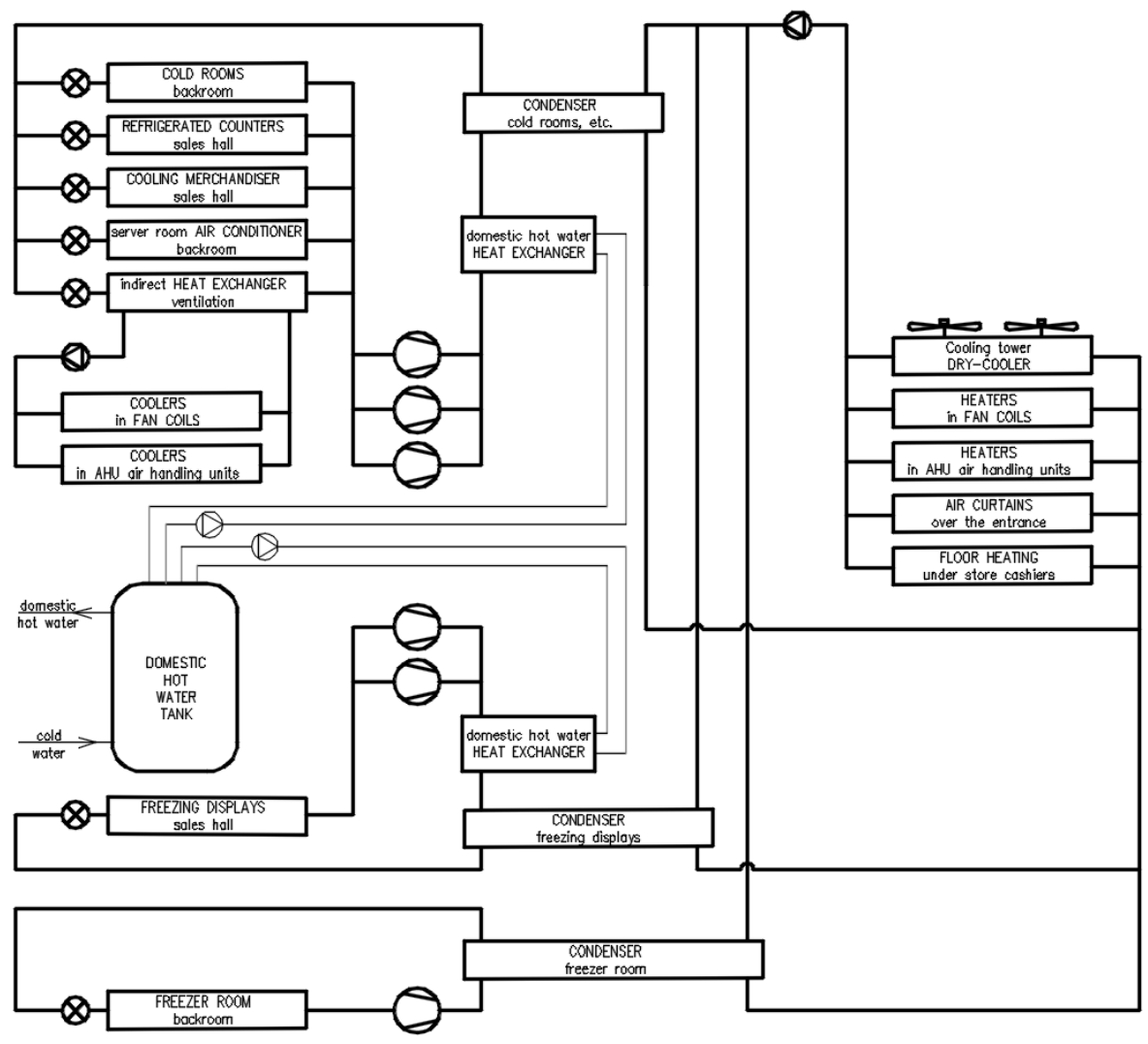

Fig. 3. Diagram of technical and technological installations WHRS used in the market.

For the production of hot water for the needs of a commercial facilities, the heat recovery system used superheated refrigerant vapor from the units 1 and 2 (fig. 3). Heat of superheated vapor in cold room circuit (with plus-working temperature) is a maximum of $\mathrm{Q}_{\mathrm{sh}}=30 \mathrm{~kW}$, while in the circulation of freezing displays (with minus-working temperature) up to $\mathrm{Q}_{\mathrm{sh}}=5 \mathrm{~kW}$.

Two refrigerant - water heat exchangers, two circulation pumps and a domestic hot water tank (hot water reservoir HWR) with a volume of $1000 \mathrm{dm}^{3}$ were designed. 
The target water temperature in the tank is $55^{\circ} \mathrm{C}$. An additional electric heater is provided in the reservoir for the elimination of Legionella bacteria (it will allow the water to be heated once a week to $70^{\circ} \mathrm{C}$ ). This heater with a power of $5 \mathrm{~kW}$, also functions as a booster, when the heat recovery system does not provide a sufficiently high temperature of hot water.

For the heating needs of the facility, a heat recovery system for the condensation of refrigerant vapor from all refrigerating units is installed. It is also a cooling installation for condensers of refrigerating units. The waste heat recovery installation has been designed so that it can be fully utilized, as well as redirection of power to individual receivers, depending on the current demand. The hot heat-transfer fluid, which is an aqueous glycol solution, is directed to 4 air curtains located above the entrance door, low-temperature underfloor heating under four cash boxes with a cashiers, air heaters of three air handling units and heaters of eight fan coils located in the sales hall. The undeveloped heat of condensation is removed by a cooling tower (dry cooler) located outside the building. If there is no heat demand in the facility, then the heat-transfer fluid is also redirected right to the dry cooler.

\section{Conclusion}

Commercial and service construction is one of the most energy intensive in urban agglomerations. It is estimated that supermarkets consume up to 5 times more energy per square meter than other objects. Therefore, it is important to properly design installations responsible for the heating and cooling of such facilities. In this situation, it becomes the most important problem of reducing the energy needed to operate to a minimum. This is only possible through close cooperation of designers of different industries already at the stage of establishments. Mutual understanding of the needs of reducing operating costs (even at the cost of higher investment) will reduce energy consumption.

\section{References}

1. ASHRAE Handbook - Refrigeration (2018)

2. I. Dincer, M. Kanoglu, Refrigeration systems and applications (2010)

3. S. K. Wang, Handbook of air conditioning and refrigeration (2001)

4. A.R. Trott, T. Welch, Refrigeration and air-conditioning (2000)

5. W. F. Stoecker, Refrigeration Handbook (1998)

6. H. J. Macintire, Handbook of mechanical refrigeration (1928)

7. T. P. Mali, M. Saini, A. V. Joshi, J4R 3, 4 (2017)

8. T. Patil, N. Medhane, Y. Mahapure, K. Nagmoti, A. Dube, IJSRM 3, 6 (2015)

9. D. T. Reindl, T. B. Jekel, ASHRAE J. 49, 8 (2007)

10. D. Ross, S. Burns, I. Hunt, M. Mokhtar, Appl. Energ. 195, 11 (2017)

11. M. Szwajkajzer, Chłodnictwo i klimatyzacja 5, 4 (2015)

12. D. Staniszewski, Z. Bonca, Technika Chłodnicza i Klimatyzacyjna 1, 9 (2006)

13. M. Żak, A. Żółtaniecki, Technika Chłodnicza i Klimatyzacyjna 12, 8 (2006)

14. D. Staniszewski, W. Targański, Odzysk ciepła $w$ instalacjach chłodniczych i klimatyzacyjnych (2007)

15. S. Sawalha, IJR 36, 12 (2013) 